\title{
AS SANÇÕES ADMINISTRATIVAS NO CÓDIGO DE DEFESA DO CONSUMIDOR PARA A CONCRETIZAÇÃO DA FUNÇÃO SOCIAL DA EMPRESA
}

\section{Eduardo Felipe Veronese ${ }^{1}$}

RESUMO: A atividade empresarial não deve estar pautada exclusivamente pela obtenção de lucro, apesar de ser esse seu objetivo precípuo. Deve, também, primar pela probidade e justiça nas suas relações, com atuação pautada na boa-fé objetiva, bem como pela valorização do princípio da dignidade da pessoa humana, objetivando cumprir seu papel na sociedade. Especificamente no que tange às relações de consumo, o CDC estabeleceu as sanções administrativas como forma de evitar condutas reprováveis. Através do desestimulo às infrações administrativas no direito do consumidor, pretende-se promover o desenvolvimento e a pacificação social, com o cumprimento da função social da empresa.

Palavras-chave: Atividade Empresarial; Função Social; Boa-Fé Objetiva; Sanções Administrativas; Direitos Fundamentais.

\section{ADMINISTRATIVE PUNISHMENT IN THE CONSUMER PROTECTION CODE TO FUNCTION CONCRETIZATION SOCIAL ENTERPRISE}

\begin{abstract}
Business activity should not be based solely on profit, although this is its primary objective. It must also prevail over probity and justice in its relations, based on objective good faith, as well as on the valorization of the principle of the dignity of the human person, in order to fulfill its role in society. Specifically with regard to consumer relations, the CDC established administrative sanctions as a way to avoid reprehensible conduct. By discouraging administrative infractions in consumer law, it is intended to promote the development and social pacification, with the fulfillment of the social function of the company.
\end{abstract}

Keywords: Business Activity; Social Fuction; Objective Good-Faith; Administrative Punishment; Fundamental Rights.

\footnotetext{
${ }^{1}$ Mestrando em Direito Empresarial e Cidadania na Faculdade de Direito do Centro Universitário Curitiba, Unicuritiba - PR, (Brasil). Professor do Centro Universitário de Cascavel - Univel. E-mail: eduardoveronese@outlook.com
} 


\section{INTRODUÇÃO}

A atividade empresarial, considerada a sua inserção no atual contex to do ordenamento jurídico pátrio, não pode se valer da autonomia da vontade irrestritamente, pelo princípio da livre iniciativa, tendo em vista a ocorrência da superação da liberdade irrestrita à sua atuação, pela consagração da função social da empresa, impondo-se, assim, a atuação nos limites impostos pela Constituição Federal.

O Estado Liberal, conforme concebido, se apresenta ultrapassado, não possuindo mais condições de perpetuar seus fundamentos, sem que haja a devida mitigação, na sociedade atual. Assim, a atividade empresarial, por mais que possua por objetivo a obtenção do lucro, encontra óbice em relação ao exercício nos termos de seu interesse particular, quando não convergente ao interesse da coletividade.

O presente trabalho aborda, de início, a forma de aplicação do princípio da função social da empresa e do princípio da boa-fé no ordenamento jurídico, mais especificamente seus reflexos às relações entabuladas sob a égide das normas de direito privado. Pretende-se, a partir dos referidos fundamentos, analisar as consequências à sociedade em decorrência da atividade empresarial, o espaço por ela ocupado e as demandas a ela imputadas.

A partir desses conceitos, o ordenamento jurídico exterioriza a preocupação com a segurança das relações jurídicas, proporcionando a colaboração entre as partes para a celebração e execução dos contratos. Com efeito, o objetivo aqui traçado é vincular a forma de aplicação dos princípios constitucionais às relações consumeristas, sob a égide do Código de Defesa do Consumidor.

Através dessa lei, que visa a defesa dos interesses da parte mais fraca na relação de consumo (o consumidor), ressalta-se, também, a preocupação com a coletividade, abarcando situações que vão muito além da relação inter partes prima facie existente na celebração de contratos desse gênero, englobando ainda os deveres de cooperação, lealdade e justiça provenientes do princípio da boa-fé que deverão ser aplicados no intuito de proporcionar a harmonia social.

Posto o problema a ser enfrentado, emergem os objetivos de identificação de uma das formas pela qual optou o legislador no intuito de efetivar os interesses coletivos, mediante a atividade empresarial pautada pela boa-fé e cumprindo a sua função social. 
Nesse passo, apresenta-se a figura da sanção administrativa como possível instrumento voltado à promoção da pacificação e do desenvolvimento social, com seus regime próprio e observando, também, os princípios inseridos na Constituição Federal.

Em termos de metodologia, adota-se uma análise crítica e dialética, baseada em referencial bibliográfico.

\section{A ATIVIDADE EMPRESARIAL E A ORDEM CONSTITUCIONAL}

Conforme disposto no artigo 966 do Código Civil, "considera-se empresário quem exerce profissionalmente atividade econômica organizada para a produção ou a circulação de bens ou de serviços". Portanto, evidencia-se que a norma derivada do Código Civil italiano de 1942 deixou que permanecesse no ordenamento jurídico a distinção de tratamento despendido às atividades econômicas, tendo passado do tipo de atividade para o nível de importância econômica. Apesar disso, insta esclarecer que restou ampliado de modo considerável o alcance da tutela legal, tendo excluído da abrangência, a grosso modo, apenas os profissionais liberais, conforme disposto no parágrafo único do referido artigo. (RAMOS, 2009, p. 43)

A teoria desenvolvida por Alberto Asquini, denominada perfis da empresa, engloba o conceito de empresa consagrado no referido dispositivo legal. Segundo ele, pelo conceito econômico, a empresa poderia ser vista sob quatro diferentes perfis: objetivo (como patrimônio, complexo empresarial para exercício da atividade), subjetivo (como empresário, que produz, de forma profissional, para o mercado), corporativo (como instituição, resultado da organização do pessoal) e funcional (atividade empresarial).

Este último entendido como:

[...] razão da empresa econômica ser uma organização produtiva que opera, por definição, no tempo, guiada pela atividade do empresário, é que, sob o ponto de vista funcional ou dinâmico, a empresa aparece como aquela força em movimento que é a atividade empresarial dirigida para um determinado escopo produtivo. (ASQUINI, 1996, p. 116)

Para a análise da constituição da empresa, há que considerar duas formulações teóricas intrínsecas a ela, quais sejam, a concepção econômica, caracterizada pela alocação de recursos e coordenação de custos sociais, e a concepção jurídica, que engloba a atividade desenvolvida e suas minúcias enquanto instituição. (SANTOS, 2015, p. 12) 
Impossível olvidar, frise-se, que a essência da atividade empresarial é a busca pela obtenção do lucro, de modo que imaginar a possibilidade de funcionamento de uma empresa privada objetivando exclusivamente promover o interesse coletivo, afastando-se do benefício particular, é mero devaneio.

Entretanto, ao mesmo tempo, encontrar na atividade empresarial o intuito apenas de proporcionar riqueza aos seus detentores é gerar um conceito em sentido diametralmente oposto ao que estabelece a ordem constitucional vigente, que preza pela defesa do benefício social.

A empresa não deve ser entendida como uma entidade, mas sim como uma atividade destinada à produção, circulação e distribuição de riquezas, sendo atribuído a ela, em face de seu objetivo de resultado de natureza econômica, o direito de empresa, configurado como uma continuação imediata do direito das obrigações. (REALE, 1986, p.6)

A partir da promulgação da Constituição da República Federativa do Brasil, em 1988, considerando a dinâmica da economia capitalista, foi definido no Brasil o seu conceito de democracia (que outrora já ganhara força), pautada não apenas no modelo econômico liberal e nem apenas no modelo econômico social, mas se valendo da dialética entre os dois sistemas, tendo por escopo observar as necessidades de todas as classes sociais, que se consubstancia na razão consagradora do Estado Democrático-Social.

Dentre as alterações advindas da nova posição, destaca-se a dignidade da pessoa humana em detrimento da postura exclusivamente patrimonialista adotada anteriormente, razão pela qual todo o funcionamento do ordenamento resta focado na necessidade de atendimento aos anseios não apenas do indivíduo, mas também, e principalmente, da coletividade, de todos aqueles que suportarão os reflexos oriundos dos atos cometidos.

\footnotetext{
Concluindo - e até porque aquelas conclusões se integram nas afirmações que seguem, destas sendo pressupostos - temos que: - A Ordem Econômica na Constituição de 1988 define opção por um sistema, o sistema capitalista. - Há um modelo econômico definido na Ordem Econômica na Constituição de 1988, modelo aberto, porém, desenhado na afirmação como modelo bem-estar. - A Ordem Econômica na Constituição de 1988, sendo objeto de interpretação dinâmica, poderá ser adequada às mudanças da realidade social, prestando-se, ademais, a instrumentálas. (GRAU, 2012, p. 345)
}

Frente a esse desenvolvimento conceitual, a propriedade deixa de ser absoluta e se legitima na medida em que respeita a sua função social. Ou seja, o exercício da propriedade 
deve ocorrer de tal modo que proporcione a consagração dos direitos fundamentais do ser humano, entre eles, por exemplo, a dignidade, a cidadania e a igualdade substancial, não apenas o acréscimo patrimonial por si só, individualista.

A Constituição Federal, ao abordar os direitos e garantias fundamentais, mais especificamente no artigo $5^{\circ}$, estabelece que é garantido o direito de propriedade, bem como a propriedade atenderá a sua função social. No mesmo sentido, ao tratar sobre a ordem econômica e financeira, no artigo 170, define como fundamento a valorização do trabalho humano e a livre iniciativa, consagrando a propriedade privada e a função social da propriedade.

Apesar da aparente contradição existente nos referidos dispositivos, que tutelam, ao mesmo tempo, um interesse teoricamente individual e outro coletivo que limita o outro, o princípio da dignidade da pessoa humana é o responsável por conferir coerência ao ordenamento.

O Estado democrático de direito traz em si uma unidade de sentido que permeia toda a Constituição e orienta a compreensão dos demais princípios: a dignidade da pessoa humana, como conceito que consagra simultaneamente a autonomia privada e a autonomia pública.

Logo, muito mais importante do que discutir qual é o grau de capitalismo adotado pela Constituição é saber que a ordem econômica tem por fim assegurar a todos uma existência digna, conforme os ditames da justiça social, tal como acentua o próprio caput do art. 170. (LOPES, 2006, p. 278)

Em atendimento ao disposto na norma constitucional, o Código Civil definiu, em seu artigo 1.228, a necessidade de observar as finalidades econômicas e sociais quando do exercício da propriedade:

Art. 1.228. O proprietário tem a faculdade de usar, gozar e dispor da coisa, e o direito de reavê-la do poder de quem quer que injustamente a possua ou detenha.

$\S 1^{\circ} \mathrm{O}$ direito de propriedade deve ser exercido em consonância com as suas finalidades econômicas e sociais e de modo que sejam preservados, de conformidade com o estabelecido em lei especial, a flora, a fauna, as belezas naturais, o equilíbrio ecológico e o patrimônio histórico e artístico, bem como evitada a poluição do ar e das águas. 
Através do conceito de função social se entrelaça o direito individual de propriedade, bem como o interesse individual do proprietário, ao interesse de toda a coletividade. Nesse passo, a utilização da propriedade deve se dar atendendo a ambos os anseios, afastando a premissa da liberdade individual e absoluta. Com efeito, deixa-se de tutelar o "indivíduo" visto sob o viés liberal-burguês, cuja existência se justifica pela matriz kantiana de autodeterminação, passando-se a considerar o "sujeito", isto é, aquele ao qual são atribuídas diversas relações intersubjetivas que justificam, na sua medida, seus diversos papéis sociais. (TEPEDINO, 2008, p. 18)

O direito de propriedade abrange todos os direitos que formam o patrimônio, ou seja, aferíveis pecuniariamente, que possibilitam ao seu titular a ingerência socioeconômica, não se limitando ao direito real. Nesse aspecto, evidente se mostra a inserção da empresa no conceito de propriedade, devendo ela, também observar os preceitos constitucionais. (TEIZEN JÚNIOR, 2004, p. 150)

Por estar diretamente vinculada ao direito de propriedade, à atividade empresarial não é facultado destoar do conceito de função social, de modo que apesar da previsão constitucional de livre iniciativa e autonomia privada, consagrando a liberdade econômica, a dignidade da pessoa humana, refletida pelo bem-estar dos indivíduos, apresenta-se como fundamento da ordem econômica.

O direito civil, nele incluído o direito empresarial, não se desvincula, em momento algum, das normas inseridas na Constituição da República Federativa do Brasil, de 1988. Pelo contrário, é totalmente submetido a ela, sob pena de ineficácia de seu conteúdo, tendo em vista que o direito constitucional se afigura como a base que rege e harmoniza o sistema jurídico.

No Brasil, a ideia da função social da empresa também deriva da previsão constitucional sobre a função social da propriedade (art. 170, inciso III). Estendida à empresa, a ideia de função social da empresa é talvez uma das noções de mais relevante influência prática e legislativa no direito brasileiro. É o principal princípio norteador da "regulamentação externa" dos interesses envolvidos pela grande empresa. Sua influência pode ser sentida em campos tão díspares como direito antitruste, direito do consumidor e direito ambiental. (COMPARATO, 2008, p. 132)

Assim, o princípio da função social da empresa proporciona o diálogo entre a liberdade de iniciativa e de competição com a dignidade da pessoa humana, de modo que esse último atua como mediador da atuação empresarial. A partir do conceito da função social da empresa, tem- 
se o principal instrumento, em relação à atividade empresarial, para a efetivação dos objetivos traçados na Constituição em favor da dignidade da pessoa humana.

\section{A RELAÇÃO OBRIGACIONAL NA ATIVIDADE EMPRESARIAL}

A atividade empresarial se desenvolve por diversas formas, sendo que uma de suas etapas é a exteriorização e obtenção de seus objetivos particulares, qual seja, o lucro, mediante a celebração de vínculos obrigacionais, pela celebração de contratos com aqueles que se propõem a se valer dos bens ou serviços por ela colocados à disposição da sociedade.

O fim do individualismo do século XIX fez com que o paradigma do dirigismo contratual aflorasse conceitos que não eram utilizados com muita frequência nos sistemas anteriores, que eram, em sua grande maioria, fechados. (COSTA; GOMES, 2014, p. 6)

Os efeitos sociais proporcionados pelos contratos se tornaram mais relevantes, de modo que o reconhecimento da sua função social como princípio limitador da autonomia privada dos contratantes se fez essencial para a conformação das relações, afastando, ao menos em tese, os efeitos indesejados das desigualdades entre as partes envolvidas.

Atendendo aos objetivos inseridos na Constituição Federal, o Código Civil passou a tutelar, também, a função social do contrato, especialmente através de seu artigo 421, que dispõe que "a liberdade de contratar será exercida em razão e nos limites da função social do contrato".

Dentre esses diversos princípios norteadores do Direito, que embasam toda a estrutura jurídica, é possível mencionar o princípio da boa-fé, além da função social, como um dos principais, tendo se mostrado extremamente relevante para a organização da vida em sociedade.

E, como se demonstrou acima, quando se exige das partes contratantes o comportamento com boa-fé, passa-se a exigir destes também a prática de diversas condutas, que se somam para o bom cumprimento da prestação principal, nascendo aí a possibilidade de estudar a relação contratual como relação dinâmica, como um conjunto de atos ordenados, que levam a um fim: o adimplemento da prestação perseguida pelo credor. A ideia de contrato como processo, resulta no reconhecimento de que não apenas o devedor tem obrigações na relação contratual, mas também o credor, que deve agir com cooperação para a satisfação dos interesses principais do negócio. (BAGGIO, 2012, p. 9). 
Como bem assevera Judith Martins-Costa, a origem do princípio da boa-fé remete ao que se pode considerar a tríplice raiz, sendo proveniente do direito romano, do direito germânico e do direito francês (MARTINS-COSTA, 2000, p. 110).

A função essencial do princípio da boa-fé é temperar uma interpretação e os desempenhos estritos ou abusivos das relações entabuladas entre sujeitos de direitos dotados de autonomia para a prática dos atos da vida civil, determinando-se, assim, a medida necessária de cooperação que incumbe a cada envolvido na relação jurídica (COSTA, 1994, p. 871).

A boa-fé é responsável por traduzir o interesse social na segurança das relações jurídicas, devendo sempre haver lealdade e confiança recíprocas entre as partes, a fim de proporcionar uma colaboração na execução das obrigações inseridas no contrato celebrado.

Não resta dúvida sobre a extrema relevância que se atribui ao princípio da boa-fé no ordenamento jurídico, visto que engloba em si os padrões de lisura, ética, honestidade e probidade (BUSSATTA, 2008, p. 22). Ainda, possui por escopo servir como via de oxigenação das obrigações, permitindo que seja permeada por valores relevantes do sistema e essenciais para a exata satisfação dos interesses envolvidos.

Nesse sentido, ao tratar do princípio da boa-fé, faz-se referência, necessariamente, à boa-fé objetiva, que se constitui como princípio do direito de modo geral, fonte de deveres jurídicos não expressos, ou seja, decorrentes da incidência do princípio sobre determinada relação jurídica (MIRAGEM, 2013, p.126).

Nesse aspecto, a aplicação do princípio da boa-fé objetiva

\begin{abstract}
trata-se de incluir nos contratos, em virtude da interpretação e da construção, deveres secundários ou derivados de informação, conselho e até cooperação, assim como a proibição de certas omissões. Cria-se, assim, um dever de lealdade na contratação e na execução do contrato que está vinculado basicamente às noções de confiança e de equilíbrio. Confiança entre as partes contratantes, que devem ter e manter, uma em relação à outra, o comportamento do bom pai de família e até, conforme o caso, do parceiro sério, diligente e confiável, sob pena de responsabilidade se uma delas não corresponder à expectativa da outra (WALD, 2003, p.42).
\end{abstract}

Apesar de não haver menção expressa ao princípio da boa-fé na Constituição de 1988, apresenta-se como elemento ínsito a esta principalmente em decorrência da solidariedade. Tal condição se dá em face da exigência, por ela, de comportamento leal, probo, que deve guiar os indivíduos na vida em sociedade, de modo justo, democrático, público e digno. 
Nesse aspecto, a construção da boa-fé objetiva está intimamente atrelada ao princípio da dignidade da pessoa humana, no que diz respeito tanto ao aspecto individual quanto coletivo. Isto, pois, a carga ética contida no princípio da boa-fé, enquanto cláusula geral, denota considerável consequência jurídica social, configurada pela preocupação com a confiança gerada à sociedade (MACHADO; LIBERATO, 2012, p. 17).

Em suma, o princípio da boa-fé encontra seu fundamento maior na Constituição, mais precisamente no paradigma do Estado Democrático de Direito, responsável por transmitir forma à dignidade da pessoa humana. A partir da boa-fé é que todas as normas presentes no ordenamento jurídico, desde o preâmbulo da Constituição, devem ser regidas, o que evidencia sua extrema relevância para a garantia da harmonia social, mesmo que não reste expressamente consagrado.

Ainda, em decorrência da relação que a boa-fé objetiva mantém com a socialidade, a função social da propriedade, com previsão nos artigos $5^{\circ}$, XXII e XXIII, e 170, III, da Constituição Federal de 1988, se apresenta como mais um fundamento, especialmente por ser a confiança contratual, bem como a solidariedade, conceitos presentes na manutenção da ordem econômica.

\footnotetext{
Pela relação direta que mantém com a socialidade e com a solidariedade, a boa-fé objetiva também encontra fundamento na função social da propriedade, prevista no artigo $5^{\circ}$, inciso XXIII e artigo 170, III, da Constituição Federal de 1988. A confiança contratual, aliás, é conceito estritamente relacionado à própria manutenção da ordem econômica. (BAGGIO, 2008, p. 150)
}

Sob o prisma do Código Civil vigente, há três funções nítidas no conceito de boa-fé objetiva: a função interpretativa contida no artigo 113; a função de controle dos limites do exercício de um direito, estabelecida no artigo 187 e a função de integração do negócio jurídico constante no artigo 422.

Pela função interpretativa, conforme consta no artigo 113 do Código Civil, o princípio da boa-fé possui o objetivo de auxiliar o aplicador do direito na interpretação dos negócios jurídicos, em especial dos contratos. A aplicação do contido no referido artigo está atrelada à interpretação do artigo antecedente, o artigo 112, que traz em seu bojo a boa-fé subjetiva, visto que se vincula à vontade das partes em detrimento do sentido literal da linguagem.

Por prever que os negócios jurídicos devem ser interpretados conforme os usos do local de sua celebração, de modo que o meio que cerca o contrato toma extrema relevância para 
a análise e interpretação de seu objeto, a boa-fé objetiva presente nesse artigo guarda relação de interação com o princípio da função social dos contratos, não podendo ser pensado isoladamente (TARTUCE, 2013, p. 93).

A segunda função do princípio da boa-fé expressa no Código Civil, em seu artigo 187, é de controle, visto que adota o critério objetivo-finalístico, de modo que a afronta à boa-fé objetiva resulta na responsabilidade do agente independentemente da existência de culpa. Ao contrariar a boa-fé objetiva, estar-se-á cometendo um abuso de direito.

A terceira função está consignada no artigo 422 do Código Civil, sendo de integração do contrato. Através dela, pretendeu o legislador atribuir aos contratantes o dever de guardar a boa-fé e probidade tanto na conclusão como na execução do contrato.

Na lição de Fernando de Noronha, a função integrativa do contrato se perfaz na continuação da interpretação do contrato, para além das disposições previstas pelas partes ou impostas pela lei, tendo por finalidade fixar os direitos e obrigações das partes envolvidas. (NORONHA, 1994, p. 166)

Da integração do negócio pela boa-fé decorrem deveres acessórios que possuem por escopo preencher as lacunas deixadas pelas partes quando da celebração do contrato.

Apesar disso, deixou o legislador de incluir o período pré e pós contratual à necessária presença do princípio da boa-fé, sendo fundamentais para a criação de deveres jurídicos para as partes, em face da inexistência, nessas fases, de prestação objetiva a ser cumprida (PEREIRA, 2012. p. 18). Assim, há que se aplicar de forma extensiva a norma, a fim de viabilizar a abrangência às situações.

Apesar da consagração do princípio da boa-fé por norma infraconstitucional, sua incidência emerge sobre todas as relações jurídicas existentes na sociedade. Possui caráter de cláusula geral de observância obrigatória, devendo seu conceito jurídico ser concretizado com base em cada hipótese de sua aplicação, visto se tratar de conceito jurídico indeterminado.

Toda norma infraconstitucional que passa a produzir efeitos no mundo jurídico é dotada de presunção de constitucionalidade (MENDES; BRANCO, 2013, p. 98). Por essa razão, dada a textura semântica, se uma norma infraconstitucional admitir mais de um significado, deve se entender que ao caso é aplicável o sentido coerente com a Constituição.

Paulo Luiz Netto Lôbo defende que não há espaços distintos ou contrapostos entre as codificações. O que existe é uma unidade hermenêutica, sendo a Constituição o ápice de todo o ordenamento jurídico, conformador da elaboração e aplicação da legislação civil. (LÔBO, 2005. p. 2) 
Pelo diálogo das fontes legislativas, baseando-se nos valores consagrados pela Constituição, a consequência é um contexto mais coletivo do que individualista, que caminha rumo ao direito mais justo, de pessoas livres e iguais para conviver de forma digna numa sociedade solidária (MARQUES; MIRAGEM, 2014, p. 98).

Seguindo tal dinâmica, restou ao legislador infraconstitucional consignar expressamente os princípios da boa-fé e da função social no ordenamento jurídico por meio das codificações posteriores à promulgação da Constituição.

A Lei $n^{\circ}$ 8.078/1990, também denominada de Código de Defesa do Consumidor, trouxe em seu corpo grandes inovações, decorrentes da constitucionalização do direito civil e da nova teoria contratual, no intuito de aplicar as diretrizes constitucionais de solidariedade social e proporcionar especial atenção aos vulneráveis.

Antecipando-se ao Código Civil, o CDC previu, em seus artigos $4^{\circ}, 6^{\circ}, \mathrm{V}, 39$, V e 51, IV, o princípio da boa-fé objetiva e do equilíbrio contratual, bem como fixou regras específicas decorrentes desses princípios, evidenciando-se a especial atenção despendida em relação ao momento anterior à celebração do contrato, em face da realidade de sujeição do consumidor a contratos de massa elaborados prévia e unilateralmente pelos fornecedores.

No que tange ao direito do consumidor, o princípio da boa-fé encontra eficácia por variadas formas. Nos contratos de consumo, em decorrência da boa-fé para proteção da legítima expectativa gerada, o fornecedor fica vinculado à oferta e publicidade que fez veicular. $\mathrm{Na}$ mesma medida, a falta de informação que deveria ser apresentada pelo fornecedor faz com que o contrato não obrigue o consumidor a termos que não lhe foi oportunizado ter conhecimento ou tenha sido dificultada a sua compreensão. (MIRAGEM, 2013, p. 127)

Pelas lições de Cláudia Lima Marques, no CDC o princípio da boa-fé objetiva na formação e na execução das obrigações possui dupla função: primeiro, como fonte de novos deveres especiais de conduta durante o vínculo contratual, também chamados de deveres anexos, e, segundo, como causa limitadora do exercício dos direitos subjetivos (MARQUES, 2002, p. 48).

Para a aferição da presença ou não da boa-fé objetiva nas relações de consumo é irrelevante a intenção do fornecedor em lesar ou não o consumidor, por qualquer forma que seja. A ofensa à boa-fé, nesse prisma, ocorre quando o contrato se apresenta flagrantemente desequilibrado, mediante exacerbada vantagem econômica ao fornecedor, quando houver elevada desigualdade entre os direitos conferidos ao consumidor e as obrigações que lhe são 
atribuídas, bem como quando são frustradas as legítimas expectativas criadas na relação de consumo (KHOURI, 2005, p. 66).

Assim, em todas as fases da relação de consumo, desde o início da oferta até a execução dos termos contratados, os envolvidos precisam atuar de forma a proporcionar a satisfação dos interesses comuns, preservando o equilíbrio dessa relação.

\title{
4 SANÇÕES ADMINISTRATIVAS NO CÓDIGO DE DEFESA DO CONSUMIDOR
}

A função social do contrato está diretamente vinculada ao objetivo precípuo de pacificação social através dos efeitos do contrato, sendo que se pretende proteger os interesses coletivos através da tutela individual por parte do Estado.

\begin{abstract}
A função social do contrato e o Direito, entretanto, não é adversa ao reconhecimento dos direitos da personalidade, como aparentemente se pode achar. Pelo contrato, é de interesse nitidamente social o reconhecimento desses direitos.

Protegendo-se o indivíduo, tutela-se, por decorrência, a sociedade, cujo precípuo interesse deve ser, indubitavelmente, o bem comum, inserindo-se nessa concepção o bem de cada um, pelo desenvolvimento social e para a preservação da espécie.

$\mathrm{O}$ asseguramento de direitos inerentes no homem em função de sua própria natureza (vida, integridade física e psíquica, corpo, cadáver, honra, identidade, sigilo, liberdade, imagem entre outros), representa o caminho e a garantia da pacificação social, a fim de que todos os sujeitos de direitos possam vir a ter uma liberdade responsável e ampla conciliada com a igualdade de tratamento e de condições. Fatores esses pelos quais o Direito, seus profissionais, o estado e a sociedade civil devem lutar continuamente.
\end{abstract}

A socialização jurídica almeja o transporte da mera abstração dos direitos personalíssimos para a realizada, dando o instrumental compatível para sua tutela. (LISBOA, 2007, p. 49)

Esse conceito está diretamente vinculado à constitucionalização do direito civil, valendo-se do contrato como instrumento de pacificação social, através do interesse da sociedade em relação ao correto cumprimento das obrigações, sobrepondo-se ao liame individualista voltado exclusivamente à circulação de riquezas.

É que se existem deveres outros na relação contratual, além do dever de cumprir a prestação principal, estes deveres devem ser cumpridos antes mesmo do nascimento do vínculo 
formal, e precisam ser respeitados após o encerramento do vínculo, por se tratarem de deveres gerais e sociais de conduta, que obrigam a todos genericamente e não só aos contratantes, mas a eles principalmente.

A opção do legislador pela previsão expressa nos textos de lei de deveres de lealdade, justiça, solidariedade e igualdade, impõe a observância de condutas nesse sentido a toda a coletividade e principalmente àqueles que se inserem em relações jurídicas de maior complexidade, objetivando proporcionar a regulação da vida em sociedade, evitando-se o abuso de direito de uns sobre os outros.

Considerando os objetivos inseridos na Constituição Federal, o Código de Defesa do Consumidor não poderia seguir em outro rumo que não a observância aos princípios da função social e da boa-fé, no intuito de pacificar as relações entabuladas entre os fornecedores e os consumidores.

Para tanto, na Lei $n^{\circ}$ 8.078/1990, restou inserida a previsão legal de aplicação de sanções administrativas no âmbito do direito do consumidor, possibilitando à União, Estados, Distrito Federal e Municípios a fiscalização e controle da produção, industrialização, distribuição, publicidade de produtos e serviços e o mercado de consumo, no interesse da preservação da vida, da saúde, da segurança, da informação e do bem-estar do consumidor.

Em complemento, o Decreto $\mathrm{n}^{\circ}$ 2.181/1997, que dispõe sobre a organização do Sistema Nacional de Defesa do Consumidor (SNDC) e estabelece as normas gerais de aplicação das sanções administrativas previstas na Lei $n^{\circ}$ 8.078/1990, fixa, em seu artigo 18, que a inobservância das normas de defesa do consumidor constituirá pratica infrativa e sujeitará o fornecedor às penalidades previstas nos seus incisos.

Por sanção administrativa é possível entender "a direta e imediata consequência jurídica, restritiva de direitos, de caráter repressivo, a ser imposta no exercício da função administrativa, em virtude de um comportamento juridicamente proibido, comissivo ou omissivo" (FERREIRA, 2001, p. 34).

Portanto, ocorrendo a violação de uma norma de conduta que demanda a aplicação de uma medida repressiva como consequência, estar-se-á diante da situação ensejadora da instauração do devido processo legal para, após, se for o caso, impor uma restrição de direito, de caráter repressivo.

Em atendimento aos preceitos constitucionais, a Lei $\mathrm{n}^{\circ}$ 9.874/99, em seu artigo $2^{\circ}$, estabelece a obrigação da Administração Pública obedecer, dentre outros, aos princípios da legalidade, finalidade, motivação, razoabilidade, proporcionalidade, moralidade, ampla defesa, 
contraditório, segurança jurídica, interesse público e eficiência, definindo, ainda, os critérios a serem observados, como impessoalidade, publicidade, probidade, entre outros.

Consideradas as previsões legais, é de se entender que se houve a outorga da competência sancionadora à Administração Pública, percebeu-se que o comportamento ilícito sancionado fere o interesse público, de modo que se faz necessário desestimulá-lo. Por consequência, compete à Administração Pública, através de seus agentes impor a sanção sempre que for apurada a prática de ilícito administrativo, pois somente assim o interesse público que justifica a existência da competência sancionadora restará atendido. Portanto, a aplicação da sanção administrativa não consiste numa liberalidade à Administração Pública, mas sim competência vinculada, devendo ocorrer quando constatado o ilícito previsto em lei, após o devido processo legal. (MELLO, 2007, p. 71)

No que se refere à finalidade da sanção administrativa, "se realiza como resposta jurídica de modo a exatamente desestimular a incursão no ilícito - e possui, portanto, natureza repressiva e restritiva de direitos, podendo ser assumida como um mal, um castigo mesmo, mas apenas quando recaída sobre o infrator" (FERREIRA, 2009, p. 90).

Sendo assim, não se encaixa a sanção administrativa num conceito cuja finalidade é pura e simplesmente a punição pela ocorrência do ilícito, mas sim, em verdade, se perfaz na tentativa de desestimular a ocorrência de condutas administrativamente reprováveis, em caráter antes mesmo de repressivo, como preventivo e educativo.

Portanto, a sanção administrativa é uma medida de caráter negativo, que responde a uma conduta típica, antijurídica e administrativamente reprovável, imposta pela Administração Pública no exercício de sua função.

Ou seja, as sanções administrativas se distinguem das sanções penais especialmente na medida em que a primeira possui por escopo assegurar o bom funcionamento interno dos serviços e da ordem administrativa, enquanto a segunda busca assegurar a paz e valores sociais mais amplos. Entretanto, dependendo da natureza do bem jurídico protegido, existe a possibilidade de ocorrer, simultaneamente, implicações sancionatórias em diferentes planos de responsabilização. (OSÓRIO, 2011,p. 144)

No tocante ao Código de Defesa do Consumidor, constatando-se a infração administrativa, nos termos do artigo $55, \S 1^{\circ}$, assegurado o devido processo legal, aplicar-se-á, conforme o caso, as sanções administrativas nos termos do artigo 56 da referida lei, observandose a razoabilidade e proporcionalidade quando da sua definição. 
A aplicação das sanções administrativas, decorrente da infração ocorrida, não é restrita à fase de cumprimento dos termos acordados entre o fornecedor e o consumidor, conforme anteriormente exposto. Há que se tutelar, também, as fases pré e pós contratual, visto que nesses momentos também deve a atuação das partes ser pautada pela boa-fé, a fim de garantir não apenas a perfeita execução dos termos contratados, mas também assegurar o atendimento aos anseios da sociedade.

A afronta às normas consumeristas por parte do fornecedor abala os pilares da sociedade, perpetuando a insegurança nas relações e prejudicando o bem-estar dos consumidores. Nessa hipótese, a função social do contrato, bem como da empresa, deixa de ser consagrada e os anseios sociais, assegurados pelas normas constitucionais, restam feridos.

\footnotetext{
Assim como a propriedade, a posse e o contrato, a empresa também deve cumprir uma função social. A empresa, sem sombra de dúvidas possui uma relevante função social uma vez que é responsável pela promoção da produção e circulação de bens e serviços no mercado, pela geração de riquezas, renda, empregos, pelo pagamento de tributos aos cofres públicos, enfim, por contribuir para o desenvolvimento econômico, social e cultural da comunidade na qual encontra-se inserida. Para tanto, o empresário, ao organizar suas atividades empresariais, deverá respeitar as diversas normas jurídicas que regulamentam a utilização dos fatores de produção, tais como as normas trabalhistas, urbanísticas, ambientais, concorrenciais, consumeristas, protetivas dos direitos autorais, dentre inúmeras outras. (FIUZA; MARTINS, 2014, p. 8)
}

Por mais que o paradigma tradicional da empresa seja a obtenção do lucro, essa finalidade deve estar vinculada à obrigação da função social mensurada por uma ética solidária de modo que,

a simples dissociação entre propriedade, lucro e responsabilidades pelos impactos da atividade empresarial não pode ser aceita pelos stakeholders (trabalhadores, consumidores, ambientalistas, investidores, concorrentes e organismos internacionais) como forma de maximizar os lucros e socializar as perdas. O poder do setor empresarial reforça as exigências decorrentes da função social e da assunção de responsabilidades, e justifica tratar-se da propriedade acionária como uma propriedade-poder que deve ser exercida em benefício de toda a coletividade. (DE BORTOLI, 2008, p. 187) 
O liberalismo econômico, no conceito em que foi concebido, não consegue persistir na atual sociedade de massas, em especial pela intervenção do Estado nas relações contratuais, objetivando consolidar a proteção à parte mais fraca desse vínculo. A função social do contrato terá sido respeitada sempre que a dignidade humana reste protegida dentro do liame contratual, e sempre que seja possível vislumbrar a transparência, a confiança e a boa-fé das partes contratantes. (BAGGIO, 2008, p. 153)

Ocorre que apenas a positivação da regra não significa, necessariamente, o seu estrito cumprimento, sendo necessária a aplicação de política capaz de garantir a proteção e efetivação do mandamento, pois "o problema fundamental dos direitos do homem, hoje, não é tanto de justificá-los, mas o de protegê-los" (BOBBIO, 2004, p. 42).

No intuito de desestimular a ocorrência de infrações no âmbito do direito do consumidor é que o legislador entendeu como necessário prever no CDC as penas aplicáveis nas hipóteses de violação às normas de conduta.

Dentre as sanções administrativas existentes no âmbito do Direito do Consumidor, o CDC estabelece como possíveis a multa, apreensão do produto, inutilização do produto, cassação do registro do produto junto ao órgão competente, proibição de fabricação do produto, suspensão de fornecimento de produtos ou serviço, suspensão temporária de atividade, revogação de concessão ou permissão de uso, cassação de licença do estabelecimento ou de atividade, interdição, total ou parcial, de estabelecimento, de obra ou de atividade, intervenção administrativa e imposição de contrapropaganda.

Ainda, o parágrafo único do artigo 56 do CDC estabelece que as sanções previstas nos incisos desse mesmo artigo serão aplicadas pela autoridade administrativa, no âmbito de sua atribuição, podendo ser aplicadas cumulativamente, inclusive por medida cautelar, antecedente ou incidente de procedimento administrativo.

O Sistema Nacional de Defesa do Consumidor, criado a partir do disposto nos artigos 105 e 106 do CDC, coordenado pelo Departamento de Proteção e Defesa do Consumidor, órgão vinculado à Secretaria de Direito Econômico, do Ministério da Justiça do Brasil, possui por escopo a apuração de responsabilidade na seara administrativa, nos termos dos artigos 55 a 60 do CDC.

No mesmo sentido, vinculado ao Poder Executivo Estadual ou Municipal há o PROCON - Órgão de Proteção ao Consumidor, com intuito de acompanhar, fiscalizar e promover a conciliação nas relações de consumo, sendo-lhe possibilitado a aplicação de sanções administrativas após a apuração da ocorrência de infração. Esse poder atribuído ao 
PROCON não encontra óbice no Poder Judiciário, que possui entendimento pacificado no sentido de possibilitar a aplicação das sanções administrativas, senão vejamos:

APELAÇÃO CÍVEL - EMBARGOS À EXECUÇÃO FISCAL JULGADOS IMPROCEDENTES - ESTABELECIMENTO BANCÁRIO - MULTAS APLICADAS PELO PROCON - CÓDIGO DE DEFESA DO CONSUMIDOR PRÁTICAS ABUSIVAS EVIDENCIADAS - VENDA CASADA - TEMPO DE FILA E AUSÊNCIA DE ASSENTOS PARA PESSOAS COM DEFICIÊNCIA MANUTENÇÃO DO NOME DO CONSUMIDOR NO SERASA APÓS 05 ANOS ALEGAÇÃO DE INCONSTITUCIONALIDADE DA LEI N ${ }^{\circ}$ 13.400/2001 - NÃO CONFIGURAÇÃO - RELAÇÃO DE CONSUMO E NÃO DA ATIVIDADE FIM DAS INSTITUIÇÕES BANCÁRIAS - MULTA - REGULARIDADE - ART. 56, INC. I DA LEI No 8.078/90 - SENTENÇA MANTIDA - RECURSO DESPROVIDO. (TJPR - 4 ${ }^{\text {a }}$ C.Cível - AC - 1092653-7 - Curitiba - Rel.: Regina Afonso Portes Unânime - J. 09.05.2014).

Portanto, compete à Administração Pública, direta ou indiretamente, analisar a ocorrência de infrações administrativas e aplicar, assegurado o devido processo legal e guardada a necessária proporcionalidade, as sanções previstas no Código de Defesa do Consumidor.

Entretanto, saliente-se, conforme anteriormente exposto, a aplicação de sanção administrativa no âmbito das relações de consumo não possui o objetivo de imputar ao causador do ilícito uma punição. O que se busca através dessa política é desestimular a ocorrência de condutas administrativamente reprováveis.

Isso, pois, a própria sanção aplicada na esfera administrativa pode causar efeitos opostos ao que pretendeu o legislador quando da criação da norma. Ocorrendo uma restrição de direitos de forma elevada ao fornecedor, não necessariamente desproporcional à infração administrativa, poderá ocasionar a redução da produção ou até mesmo o encerramento das atividades da empresa, o que resultará, inevitavelmente, na redução de empregos e, consequentemente, da circulação de riquezas para a subsistência desses trabalhadores, ferindo também o princípio da dignidade da pessoa humana.

Pela previsão legal da aplicação de sanções administrativas, não apenas em relação ao Direito do Consumidor, não se pretende prejudicar o funcionamento da empresa mediante a aplicação de punições. Pretende-se preservar a harmonia das relações, nesse caso as de 
consumo, assegurando principalmente aos consumidores, polo mais frágil, a tutela de seus direitos.

A empresa tem relação direta com a efetivação dos direitos fundamentais. A continuidade da própria atividade empresarial demanda a conscientização em favor da responsabilidade para com o outro, da função social e da ética solidária. Do contrário, o funcionamento da empresa resultará comprometida em face dos efeitos da anomia produzida pela desigualdade, pela escassez de recursos ou até mesmo pela redução de consumidores.

Havendo o atendimento às normas consumeristas por parte dos envolvidos na relação, assim como boa-fé desde a fase pré contratual até a fase pós contratual, será possível proporcionar a pacificação social e o benefício coletivo, de modo que a função social da empresa estará, ao menos nesse aspecto, sendo devidamente cumprida.

\section{CONSIDERAÇÕES FINAIS}

Desde a promulgação da Constituição Federal, em 1988, a legislação infraconstitucional foi amplamente modificada, havendo a criação, modificação e até mesmo a revogação de algumas leis, tendendo a constantes evoluções, bem como a alguns retrocessos.

Apesar da existência de codificações infraconstitucionais que possuem por escopo o regramento das atividades empresariais, nesse sentido englobada a relação com fornecedores, colaboradores, consumidores e afins, a Constituição de 1988 impõe a todo o ordenamento jurídico a observância de uma série de princípios.

No que diz respeito ao direito do consumidor, a atividade empresarial deve ser pautada pelo princípio da boa-fé em todas as fases da relação, incluindo-se os momento pré e pós contratuais, de modo a preconizar a probidade e a justiça face aos consumidores.

Além disso, a relação consumerista deve primar pela observância do princípio da função social da empresa, tendo em vista que os atos decorrentes desse vínculo não estão limitados à produção de efeitos inter partes, mas irradiam consequências para toda a coletividade.

A atuação por parte da empresa tendente a causar prejuízos aos consumidores abala toda a estrutura social, prejudica a ordem econômica, gerando insegurança e reduzindo o bemestar não apenas daqueles que se valem diretamente dos bens ou serviços postos no mercado, mas também dos consumidores em potencial. 
Com intuito de desestimular a ocorrência de condutas administrativamente reprováveis, o Código de Defesa do Consumidor, com amparo, também, do Decreto ${ }^{\circ}$ 2.181/1997, estabeleceu as normas referentes às sanções administrativas no âmbito da relação consumerista, especificando as competências e formas de aplicação das consequências jurídicas que até mesmo podem alcançar outros sujeitos que não apenas o infrator.

Nesse contexto, as sanções administrativas no âmbito do direito do consumidor, objetivando desestimular os atos contrários à boa-fé objetiva na atuação empresarial, assumem extrema relevância social, pois contribuem decisivamente para o funcionamento da vida social, na medida em que direciona os objetivos da empresa à efetivação da função social que lhe é exigida pelos princípios consagrados na Constituição Federal.

\section{REFERÊNCIAS}

ASQUINI, Alberto. Perfis da empresa. Trad. Fábio Konder Comparato. Revista de direito mercantil, industrial econômico e financeiro, São Paulo, ano XXXV, n. 104, out/dez. 1996.

BAGGIO, Andreza Cristina. Novos paradigmas para uma nova sociedade: a sociedade de consumo e as relações contratuais. SCIENTIA IURIS, Londrina, v. 12, p. 139-154, 2008.

BOBBIO, Norberto. A era dos direitos. Rio de Janeiro: Elsevier, 2004, p. 42.

BONAVIDES, Paulo. Do Estado Liberal ao Estado Social. 10. ed. São Paulo: Malheiros, 2011.

COELHO, Fábio Ulhoa. Curso de direito comercial: direito de empresa. 1. vol. 17. ed. São Paulo: Saraiva, 2013.

COMPARATO, Fábio Konder; SALOMÃO FILHO, Calixto. O poder de controle na sociedade anônima. 5. ed. Rio de Janeiro: Forense, 2008.

COSTA, Mário Julio de Almeida. Direito das obrigações. 6. ed. Coimbra: Almedina, 1994.

COSTA, Patricia Ayub da; GOMES, Sergio Alves. O princípio da boa-fé objetiva à luz da Constituição.

Disponível

em:

<http://www.conpedi.org.br/manaus/arquivos/anais/salvador/patricia_ayub_da_costa.pdf >. Acesso em: 02.ago.2018.

DE BORTOLI, Andrea. A função social da empresa e suas implicações na governança corporativa e na gestão de stakeholders. In: Revista de Direito Empresarial $\mathrm{n}^{\circ}$ 9, janeiro/junho 2008, Editora Juruá, 2008.

FERREIRA, Daniel. Sanções administrativas. São Paulo: Malheiros, 2001. 
FERREIRA, Daniel. Teoria geral da infração administrativa a partir da Constituição Federal de 1988. Belo Horizonte: Fórum, 2009.

FIUZA, César; MARTINS, Thiago Penido. A função social no direito privado: uma análise crítica acerca das empresas individuais de responsabilidade limitada. Disponível em: $<$ http://www.publicadireito.com.br/artigos/?cod=122e27d57ae8ecb3>. Acesso em: 02.fev.2018.

GRAU, Eros. A ordem econômica na Constituição de 1988. 15ª Ed. São Paulo: Malheiros, 2012.

KHOURI, Paulo Roberto Roque Antonio. Direito do Consumidor: contratos, responsabilidade civil e defesa do consumidor em juízo. 2. ed. São Paulo: Atlas, 2005.

LISBOA, Roberto Senise. Contratos Difusos e Coletivos. São Paulo: Revista dos Tribunais, 2007.

LÔBO, Paulo Luiz Netto. Teoria geral das obrigações. São Paulo: Saraiva, 2005.

LOPES, Ana Frazão de Azevedo. Empresa e Propriedade: função social e abuso de poder econômico. São Paulo: Quartier Latin, 2006.

MACHADO, Gabriela Rios; LIBERATO, Gustavo Tavares Cavalcanti. O princípio da boafé objetiva como um direito fundamental implícito na Constituição Federal de 1988. Disponível em: <http://www.mpce.mp.br/esmp/publicacoes/edi001_2012/artigos/17_Gabriela.Rios.Machado. pdf>. Acesso em: 02.ago.2018.

MARQUES, Cláudia Lima. Contratos no Código de Defesa do Consumidor: o novo regime das relações contratuais. 4. ed. rev. atual. e ampl. São Paulo: Revista dos Tribunais, 2002.

MARQUES, Cláudia Lima; MIRAGEM, Bruno. O novo direito privado e a proteção dos vulneráveis. 2. ed. rev., atual. e ampl. São Palo: Revista dos Tribunais, 2014.

MARTINS-COSTA, Judith. A boa-fé no direito privado: sistema e tópica no processo obrigacional. 1. ed, 2. tir. São Paulo: Revista dos Tribunais, 2000.

MELLO, Rafael Munhoz de. Princípios Constitucionais de Direito Administrativo Sancionador: As Sanções Administrativas à Luz da Constituição Federal de 1988. São Paulo: Malheiros, 2007.

MENDES, Gilmar Ferreira; BRANCO, Paulo Gustavo Gonet. Curso de direito constitucional. 8. ed. rev. e atual. São Paulo: Saraiva, 2013.

MIRAGEM, Bruno. Curso de direito do consumidor. 4. ed. rev., atual. e ampl., São Paulo: Revista dos Tribunais, 2013.

NORONHA, Fernando. $O$ direito dos contratos e seus princípios fundamentais: autonomia privada, boa-fé, justiça contratual. São Paulo: Revista dos Tribunais, 1994. 
OSÓRIO, Fábio Medina. Direito Administrativo Sancionador. 4. ed. São Paulo: Revista dos Tribunais, 2011.

PEREIRA, Caio Mário da Silva. Instituições de direito civil: Contratos. 3. vol. 16. ed. Rio de Janeiro: Forense, 2012.

RAMOS, André Luiz Santa Cruz. Curso de Direito Empresarial: o novo regime jurídicoempresarial brasileiro. 2. ed. Salvador: JusPodium, 2009.

REALE, Miguel. O Projeto de Código Civil: situação atual e seus problemas fundamentais. São Paulo: Saraiva, 1986.

TARTUCE, Flávio. Direito Civil: Teoria geral dos contratos e contratos em espécie. 3. vol. 8. ed. rev., atual. e ampl. São Paulo: Método, 2013.

TEIZEN JÚNIOR, Augusto Geraldo. A função social no código civil. São Paulo: Revista dos Tribunais, 2004.

TEPEDINO, Gustavo. Temas de direito civil. 1. vol. 4. ed. Rio de Janeiro: Renovar, 2008.

WALD, Arnoldo. O novo Código Civil e o solidarismo contratual. Revista de direito bancário, do mercado de capitais e da arbitragem. São Paulo: Revista dos Tribunais. a. 6, n. 21, jul.-set. 2003. 